\footnotetext{
(2)
}

\title{
THE EFFECT OF FINANCIAL ATTITUDE AND FINANCIAL KNOWLEDGE ON COMPANY PERFORMANCE WITH FINANCIAL DECISIONS AS INTERVENING VARIABLES: A BEHAVIORAL FINANCE PERSPECTIVE
}

\author{
Siti Aisyah Hidayati ${ }^{1}$, Sri Wahyulina ${ }^{2}$, Embun Suryani ${ }^{3}$ \\ ${ }^{1}$ Faculty of Economics and Business, Mataram University, sitiaisyahhidayati@unram.ac.id \\ ${ }^{2}$ Faculty of Economics and Business, Mataram University, sriwahyulina@yahoo.co.id \\ ${ }^{3}$ Faculty of Economics and Business, Mataram University, embunsur74@gmail.com
}

\begin{tabular}{|c|c|}
\hline [CLE INFO & ABSTRACT \\
\hline 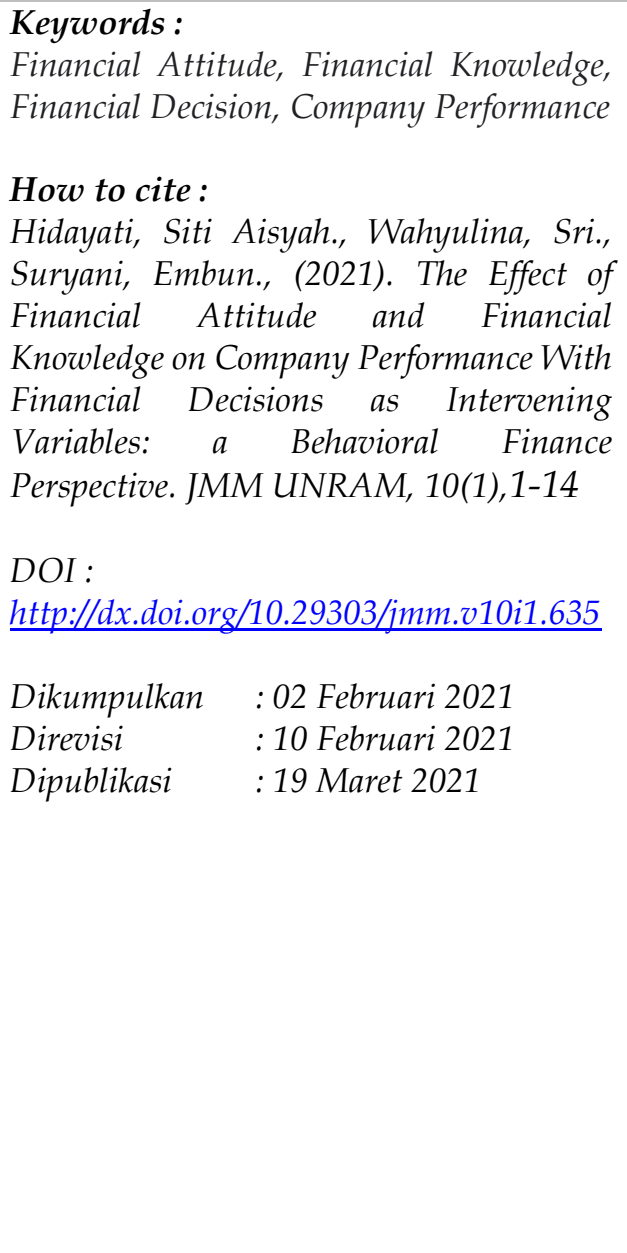 & $\begin{array}{l}\text { This study aims to analyze the effect of Financial } \\
\text { Attitude and Financial Knowledge on Company } \\
\text { Performance with Financial Decision as an } \\
\text { Intervening Variable on Small Medium Enterprises } \\
\text { Owners in Lombok Island. This research's theoretical } \\
\text { contribution is expected to contribute to the } \\
\text { knowledge and development of behavioral finance } \\
\text { theory related to Financial Decision-making and } \\
\text { Company Performance in Small Medium Enterprises. } \\
\text { Besides, it is also hoped that behavioral finance will } \\
\text { become a subject in the financial management course. } \\
\text { Furthermore, this research's practical contribution is } \\
\text { expected to provide input, suggestions, and } \\
\text { recommendations to the NTB Provincial } \\
\text { Government's policymakers in making policies } \\
\text { related to SMEs development. } \\
\text { This research is research based on a quantitative } \\
\text { approach, with this type of explanatory research. The } \\
\text { study population was all SMEs in Lombok Island. The } \\
\text { sampling was carried out by non-probability } \\
\text { selection, namely using judgment sampling, selecting } \\
\text { SMEs engaged in the pottery industry and had } \\
\text { already exported. Of the existing population, there are } \\
\text { 35 (Thirty-Five) SMEs that can be taken as samples. } \\
\text { Respondents in this study are the owners of each of } \\
\text { these SMEs. The data collection technique used in this } \\
\text { study was to use a questionnaire. The data obtained } \\
\text { will be processed as needed by using GSCA } \\
\text { (Generalized Structured Component Analysis) }\end{array}$ \\
\hline
\end{tabular}




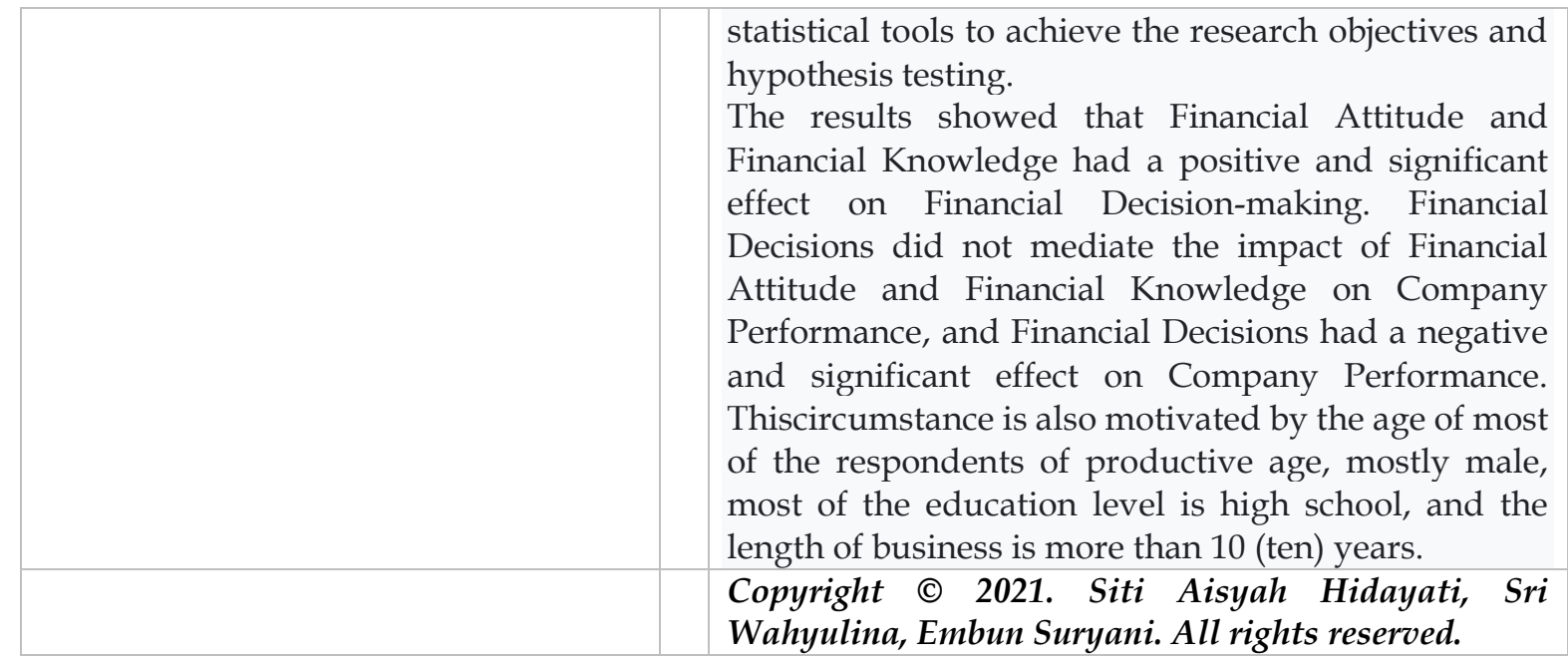

\section{INTRODUCTION}

\subsection{Background}

Financial science is based on the assumption that people will be rational in making financial decisions. On the one hand, if the decision is faced with an element of uncertainty associated with economy and portfolio, then people will make use of common sense. Humans are believed to have always been inseparable from bias during the decision-making process, leading financial decision-makers to experience mistakes. On this basis, it can be said that the elements of behavior and action or, in other words, psychology also affect financial decision-making. It's called behavioral finance.

Behavioral finance can be defined as applying psychology to financial science in Financial Decision making in households, markets, and organizations. Eagly and Chaiken (1993) stated that two factorsimpact behavioral finance: Financial Attitude and Financial Knowledge. Financial Attitudes are defined as applying economic principles to create and sustain value through appropriate decision making and resource management. Financial Attitudes can be reflected in the following six concepts: Fuenham (1984) in Klontz (2011), namely: Obsession, Power, Effort, Inadequacy, Retention, and Security. Financial Knowledge can be obtained from formal education and formal-informal sources. Nababan and Sadalia (2011) stated that Financial Knowledge includes several aspects of finance, namely: Basic Personal Finance, Money Management, Credit and Debt Management, Savings, Investment, Risk Management. Research conducted by Mien and Thao (2015) worked on Vietnamese society, stated that Financial Attitudes and Financial Knowledge have a significant positive relationship with financial management behavior. Amanah et al. (2016) noted that Financial Knowledge and Financial Attitudeaffect personal financial management behavior. Wiharno (2018) stated that the variables Financial Knowledge, economic behavior, and Financial Attitude partially have a significant positive effect on personal financial management. Humairo (2018), (1) there is a positive influence of Financial Knowledge on Financial Management Behavior in Micro, Small Medium Enterprise (SMEs) players in the Batik Handicraft Center of Bantul Regency, (2) there is a positive influence on Financial Attitudes on Financial Management Behavior in SMEs in the Batik Handicraft Center of Bantul Regency, (3) Positive Personality towards Financial Management Behavior in SMEs, Batik Handicraft Center, Bantul Regency. Lianto and Elizabeth (2017) stated that Financial Knowledge and Financial Attitudes do not significantly affectfinancial behavior. Herdjiono 
and Damanik (2016) said that Financial Knowledge does not involve financial management behavior. Hidayati et al. (2019) stated that Financial Attitudes and Financial Knowledge have a positive and significant effect on Financial Decisions, meaning that the better the Financial Attitudes and Financial Knowledge of the SMEs managersandowners, the better they are in making Financial Decisions. The relationship with Company Performance could be shown by the research of Syahrir et al. (2019), which stated that Financial Decisions have a negative and significant effect on Company Performance. The results of the study by Tuffour et al. (2020) noted that the Financial Literacy (awareness, attitude, and knowledge) of SME managers has a positive and significant effect on the performance (financial and nonfinancial) of SMEs in Ghana. In contrast to Akhtar and Liu (2018), Financial Knowledge and Financial Attitudedo not affect SMEs performance in Pakistan. Based on this research gap, Financial Decisions are used as an intervening variable, which will mediate Financial Knowledge and Financial Attitude towards Company Performance.

Behavioral finance studies the aspects of decision making in finance. Based on decision-making actors, the scope of behavioral finance groups into four categories, including investor behavior in the capital market, managerial behavior in Financial Decision making, the conduct of government officials in managing state finances, and household behavior in financial management (Supramono et al., 2010: 18). Based on the previous statement, Small Medium Enterprises (SMEs) are included in the objects that can be examined by looking at managers' behavior in decision-making and are financial institutions (Gumanti, 2009: 8).

SME is an organization that has an interest in behavioral finance. Various internal weaknesses that affect performance and success or failure include inadequacy in management, weak decision-making, inexperience, inadequate financial supervision, and too small business scale (Idrus, 1999: 18). Weak decision-making relates to SMEs entrepreneurs' behavioral finances in making decisions to affect SMEs performance. As mentioned before, it is necessary to research the influence of Financial Attitude and Financial Knowledge on Company Performance with Financial Decisions as an intervening variable in Lombok Island SMEs.

\subsection{Research purposes}

The purposes of this study are to analyze:

1. The effect of Financial Attitude on the Financial Decisions of SMEs in Lombok Island.

2. Influence of Financial Knowledge on Financial Decisions of SMEs in Lombok Island.

3. Financial Attitude effect on Company Performance with Financial Decisions as an intervening variable in Lombok Island SMEs.

4. Financial Knowledge influencesonCompany Performance with Financial Decisions as an intervening variable in Lombok Island SMEs.

5. The effect of Financial Decisions on Company Performance in SMEs in Lombok Island.

\section{LITERATURE REVIEW AND EMPIRIC STUDY}

\subsection{Literature Review}

According to De Bondt et al. (2008), they stated that "Behavioral finance is the study of how psychology impacts Financial Decisions in households, market, and organizations," which means a study of how psychology impacts Financial Decisions in households, markets, and organizations. Meanwhile, according to Pompian (2006), Behavioral Finance, commonly defined as the application of psychology to finance. Shefrin's (2005) in Forbes (2009), Behavioral finance is the study of how psychological phenomena impact financial 
behavior. Meanwhile, according to Lintner (1998:7), behavioral finance, "the study of humans interpret and act on information to make informed investment decisions," means that behavioral finance is the study of how humans interpret and act on information to make investment decisions. So the elements of human attitudes and actions are the determining factors in investing. So that Behavioral finance, in simple terms, can be defined as the application of psychology to the discipline of finance in making Financial Decisions in households, markets, and organizations.

Eagly and Chaiken (1993) stated that two factors impact behavioral finance: Financial Knowledge and Financial Attitudes. Financial Attitude is defined as applying financial principles to create and sustain value through appropriate decision making and resource management. Financial Attitudes can be reflected in the following six concepts: Fuenham (1984) in Klontz (2011), namely: 1) Obsession, 2) Power, 3) Effort, 4) Inadequacy, 5) Retention, and 6) Security.

In general, a person's lack of Financial Knowledge is caused by education, assuming that education can increase Financial Knowledge, resulting in more effective Financial Decision-making (Scott, 2010 in Robb and Woodyard, 2011). Financial Knowledge can be obtained from formal education and formal-informal sources. This formal education is such as high school programs or lectures, seminars, and out-of-school training classes. Meanwhile, informal sources can be obtained from the surrounding environment, such as parents, friends, co-workers, and their own experiences. Nababan and Sadalia (2012) stated that Financial Knowledge includes several aspects in finance as follows: 1) Basic Personal, 2) Finance, 3) Money Management, 4) Credit and Debt Management, 5) Savings, 6) Investment, 7) Management Risk.

\subsection{Empiric Study}

Some behavioral finance research has been directed at analyzing the relationship between individual psychological factors and Financial Decisions. One ofthemis perceptions and psychologicalfactors in debtdecisionmaking (Supramono and Putlia, 2010). Furthermore, Mien and Thao (2015) worked on Vietnamese people, stated that Financial Attitudes and Financial Knowledge have a significant positive relationship with financial management behavior. Amanah et al. (2016) noted that Financial Knowledge and Financial Attitudeaffect personal financial management behavior. Wiharno (2018) stated that the variables Financial Knowledge, financial behavior, and Financial Attitude partially have a significant positive effect on personal financial management. Humairo (2018)stated that (1) there is a positive influence of Financial Knowledge on financial management behavior in SMEs players in the Batik Handicraft Center of Bantul Regency, (2) there is a positive influence on Financial Attitudes on financial management behavior in SMEs in the Batik Handicraft Center of Bantul Regency, (3) Positive personality towards financial management behavior in SMEs, Batik Handicraft Center, Bantul Regency. Lianto and Elizabeth (2017) stated that Financial Knowledge and Financial Attitudes do not significantly affect financial behavior. Herdjiono and Damanik (2016) said that Financial Knowledgedoes not involve financial management behavior. Hidayati et al. (2019) stated that Financial Attitudes and Financial Knowledge have a positive and significant effect on Financial Decisions, meaning that the better the Financial Attitude and Financial Knowledge of managers and owners of SMEs, the more courageous they are in making Financial Decisions. The relationship with Company Performance can be shown by the research of Syahrir et al. (2019), which stated that Financial Decisions have a negative and significant effect on Company Performance. Akhtar and Liu (2018) stated that Financial Knowledge and Financial Attitudedo not affect SMEs performance in Pakistan. In contrast to the results of research by Tuffour et al. (2020) 
stated that the financial literacy (awareness, attitude, and knowledge) of SMEs managers has a positive and significant effect on the performance (financial and non-financial) of SMEs in Ghana. Other research related to behavioral finance in SMEs such as mental accounting and its impact on Company Performance through working capital placement in Small Medium Enterprises on the Lombok Island (Hidayati, Wahyulina, Wardani and Negara, 2015), The influence of risk attitudes on Company Performance through working capital placement decisions (Hidayati, Wahyulina, andWidiana, 2016), behavioral finance and its effects on debt decision making (Hidayati,Wahyulina, Suryani, 2017) and behavioral finance's influence on Company Performance through debt decision making (Studies on Small Medium Enterprises (SMEs) on the Lombok Island) (Hidayati, Wahyulina, and Suryani, 2018).

\section{RESEARCH METHODS}

\subsection{Research Approach}

This research is a research-based on a quantitative approach;the explanatory research analyzes one variable's effect on another. This study examines the impact of Financial Attitude and Financial Knowledge on Company Performance with Financial Decisions as an intervening variable for SMEs in Lombok Island.

\subsection{Research sites}

This research wasconducted on pottery SMEs that export on the island of Lombok.

\subsection{Research Population}

The study population was all SMEs in Lombok Island, 64,693 units ( Cooperation Agency of NTB Province, 2018).

\subsection{Sampling technique}

The sampling technique is carried out by non-probability sampling, judgment sampling, selecting samples with specific considerations. Samples taken are SMEs engaged in the pottery industry and have already exported. The concern used in choosing these SMEs is that producing and selling pottery, mainly for export, is determined by the psychological factors of SMEs manager and owner. The sample taken from the existing population is 35 SMEs in Lombok Island.

\subsection{Unit of Analysis}

The research analysis unit is SMEs engaged in the pottery business and has exported 35 SMEs in Lombok Island. Respondents in this study are managers who are also owners of each of these SMEs.

\subsection{Research variable}

This study uses three types of variables, namely independent variables, intervening variables, and dependent variables.

1. The Independent variable is Financial Attitudes and Financial Knowledge.

2. The intervening variableisFinancial Decisions.

3. The dependent variable is Company Performance.

\subsection{Analysis Tools}

The data obtained processed according to the analysis's needs to achieve the research objectives and hypothesis testing. In this study, the data received was tested using 
Generalized Structured Component Analysis (GSCA). GSCA was developed by Heungsun Hwang, Hec Montreal, and YhoshioTahane in 2004 (Solimun, 2012).

\section{RESULTS AND DISCUSSION}

\subsection{Generalized Structured Component Analysis Results}

\subsubsection{A measure of Fit Structural Model}

AFIT (Adjusted FIT) is similar to adjusted $\mathrm{R}^{2}$ in the regression analysis. AFIT can be used for model comparisons. The model with the most significant AFIT value can be chosen among the better models (Solimun, 2012).

Table4.1.

Test Results Measure of fit Structural Model

\begin{tabular}{lcccc}
\hline & Measure & Std.Error & 95\%CI_LB & 95\%CI_UB \\
\hline FIT & 0.2342 & 0.0177 & 0.2261 & 0.2976 \\
Adjusted FIT (AFIT) & 0.1901 & 0.0188 & 0.1815 & 0.2572 \\
GFI & 0.9881 & 0.0027 & 0.978 & 0.9899 \\
\hline
\end{tabular}

The results of testing the Measure of Fit Structural Model are based on Table 4.1. shows that the proportion of variable variants explained by the model is 19.01 percent, or the diversity of Financial Attitudes, Financial Knowledge, Financial Decisions, and Company Performance described by the model is 19.01 percent. At the same time, 75.84 percent is explained by other factors, such as social environment and ways of socializing, habitual aspects, locus of control (Joo et al., 2003). The Goodness Fit of Index (GFI), whichis0.9881, indicates that the model is fit because it is close to the value of 1 (one).

\subsubsection{Measurement Model of Each Variable}

The variable Financial Attitudes (X1) has 6 indicators, namely: Obsession (X1.1), Power (X1.2), Effort (X1.3), Inadequacy (X1.4), Retention (X1.5) and Security (X1 .6). Each indicator has one statement item. This variable has reflective indicators. The Loading Estimate values for each indicator, AVE, and Alpha are as follows.

Table 4.2.

Estimates of Loadings:VariableFinancial Attitudes AVE $=0.3893$, Alpha $=0.6676$

\begin{tabular}{lcccc}
\hline \hline & Estimate & Std.Error & 95\%CI_LB & 95\%CI_UB \\
\hline X11 & 0.2278 & 0.1429 & -0.4595 & 0.2368 \\
X12 & 0.1428 & 0.1533 & -0.3232 & 0.2746 \\
X13 & 0.3449 & 0.1612 & -0.4208 & 0.3424 \\
X14 & 0.3101 & 0.1465 & -0.4635 & 0.2663 \\
X15 & 0.4173 & 0.1807 & -0.4973 & 0.3622 \\
X16 & -0.1249 & 0.1731 & -0.2255 & 0.3712 \\
\hline
\end{tabular}

The computational measurement model results for the Financial Attitudes variable in table 4.2 reveal that the six indicators are valid to reflect the Financial Attitudes variable's measurement. It is proven by the loading estimate value of the six hands between the $95 \%$ CI_LB and 95\% CI_UB values. Itreflects that the correlation among all the variables' indicators is positive and significant in reflecting the latent variables.Based on the data analysis results, when viewed from the loading estimate value obtained by each indicator, the Retention indicator with the item statement "I spend sparingly" is the most dominant in reflecting the variable Financial Attitudes. 
The Average Variance Extracted (AVE) value is 0.3893 . When compared to the square root of AVE value oftheFinancial Attitudes variable with the correlation value between other latent variables in the model, it can be said that this variable has good discriminant validity because the square root of the AVE value is greater than the correlation value of all other latent variables. Thus, the research instrument used to measure the Financial Attitudes variable fulfills the discriminant validity criteria. Data analysis results using the GSCA method provide that the alpha value obtained is 0.6676 , which means that this variable has the right internal reliability consistency because it is more significant than 0.6.

The test results show that managers and owners of SMEs Financial Attitudes are most reflected by retention with the statement "I spend economically" with a mean value of 4. Thisvalue means that the SME manager and owner have calculated the costs incurred in making Financial Decisions.

Table 4.3.

Estimates of Loadings:VariableFinancial Knowledge $\mathrm{AVE}=\mathbf{0 . 3 8 9 3}, \mathrm{Alpha}=\mathbf{0 . 6 6 7 6}$

\begin{tabular}{lcccc}
\hline \hline & Estimate & Std.Error & $95 \%$ CI_LB & 95\%CI_UB \\
\hline X21 & 0.2739 & 0.0745 & 0.1114 & 0.4058 \\
X22 & 0.2755 & 0.088 & 0.0436 & 0.3896 \\
X23 & 0.2758 & 0.0735 & 0.1381 & 0.4485 \\
X24 & 0.2192 & 0.0941 & -0.0848 & 0.354 \\
X25 & 0.1513 & 0.086 & -0.065 & 0.2898 \\
X26 & 0.3336 & 0.0778 & 0.2102 & 0.466 \\
\hline
\end{tabular}

The computational measurement model results for the Financial Knowledge variable in table 4.3 show that the six indicators are valid for reflecting the Financial Knowledge variable's measurement. It is proven by the loading estimate value of the six hands between the 95\% CI_LB and 95\% CI_UB values. It reflects that the correlation among all the variables' indicators is positive and significant in reflecting the latent variables. Based on the results of data analysis, when viewed from the loading estimate value obtained by each indicator, the Risk Management indicator with the item statement "I apply risk management in Financial Decision making: a) Identifying exposures to the risks faced; $b$ ) Identifying the financial impact of the risks faced; c) Choose the most appropriate way to deal with these risks." most dominant in reflecting the Financial Knowledge variable.

The AVE value is 0.4086 . When compared with the square root of AVE value of the Financial Knowledge variable with the correlation value between other latent variables in the model, it can be said that this variable has good discriminant validity because the square root ofthe AVE value is greater than the correlation value of all other latent variables. Thus, the research instrument used to measure the Financial Attitudes variable fulfills the discriminant validity criteria. Data analysis results using the GSCA method show that the alpha value obtained is 0.6676 , which means that this variable has the right internal reliability consistency because it is more significant than 0.6.

The test results show that risk management most reflects the Financial Knowledge of managers and owners of SMEs with the statement, "I apply risk management in Financial Decision making: a) Identifying exposures to the risks faced; b) Identifying the financial impact of the risks faced; c) Choose the most appropriate way to deal with these risks. " with 
a mean value of 3.85. This result means that not all SMEs managers and owners can apply risk management to make Financial Decisions.

Table 4.4.

Estimates of Loadings: Financial Decision Variables AVE $=0.2382$, Alpha $=0.7257$

\begin{tabular}{lcccc}
\hline \hline & Estimate & Std.Error & 95\%CI_LB & 95\%CI_UB \\
\hline Y11 & 0.2425 & 0.1487 & -0.1314 & 0.4203 \\
Y12 & 0.2232 & 0.1454 & -0.1913 & 0.4169 \\
Y13 & 0.0989 & 0.1184 & -0.0894 & 0.3314 \\
Y14 & 0.1379 & 0.1528 & -0.1348 & 0.4412 \\
Y15 & 0.1579 & 0.1396 & -0.1811 & 0.3709 \\
Y16 & 0.2822 & 0.1152 & -0.0578 & 0.4181 \\
Y17 & 0.0659 & 0.0887 & -0.0876 & 0.2496 \\
Y18 & 0.1979 & 0.1158 & -0.1141 & 0.3169 \\
Y19 & 0.079 & 0.0912 & -0.0779 & 0.3466 \\
Y110 & -0.2316 & 0.1351 & -0.5641 & 0.0157 \\
Y111 & -0.0362 & 0.1227 & -0.2938 & 0.2127 \\
Y112 & 0.0347 & 0.1194 & -0.1897 & 0.2509 \\
Y113 & 0.048 & 0.1168 & -0.1601 & 0.2889 \\
\hline
\end{tabular}

The computational Financial Decision variable ofthemeasurement model results in table 4.4 shows that the two indicators are valid for reflecting the Financial Decision variable's measurement. It is proven by the loading estimate value of the two hands between the 95\% CI_LB and 95\% CI_UB values.It reflects that the correlation among all the indicator variables is significant in reflecting the latent variables.Based on the data analysis results, when viewed from the loading estimate value obtained by each indicator, the investment decision indicator with the placement of funds for working capital with the statement item "checking for bad credit levels" most dominantly reflects the variable Financial Decision.

The AVE value of 0.2382 . When compared with the square root of AVE value of the Financial Decision variable with the correlation value between other latent variables in the model, it can be said that this variable has good discriminant validity because the square root of the AVE value is greater than the correlation value of all other latent variables. Thus, the research instrument used to measure the Financial Decision variable meets the criteria for discriminant validity. Data analysis results using the GSCA method show that the alpha value obtained is 0.7257 , which means that this variable has the right internal reliability consistency because it is more significant than 0.6.

The test results show that the manager and owner of SMEs Financial Decisionsare most reflected by the investment decision indicator with the statement "checking the level of bad credit" with a mean value of 3.7. Thisoutcome means that not all SMEs managersand owners check the SMEs level of bad credit. 
Table 4.5.

Estimates of Loadings:Company Performance Variables (Y2) AVE $=0.2382$, Alpha $=0.7257$

\begin{tabular}{lcccc}
\hline \hline & Estimate & Std.Error & $95 \%$ CI_LB & 95\%CI_UB \\
\hline Y21 & 0.7594 & 0.6029 & -0.9417 & 1.2033 \\
Y22 & -0.2979 & 0.351 & -0.6281 & 0.625 \\
Y23 & 0.0491 & 0.414 & -0.8539 & 0.7996 \\
Y24 & -0.8 & 0.7465 & -1.3428 & 1.2443 \\
Y25 & 0.8063 & 0.6145 & -1.2339 & 1.245 \\
Y26 & 0.1403 & 0.3967 & -0.7346 & 0.745 \\
\hline
\end{tabular}

The computational measurement model results for the Company Performance variable in table 4.5 show that the two indicators are valid in forming the Company Performance variable's measurement. It is proven by the loading estimate value of the two hands between the 95\% CI_LB and 95\% CI_UB values. It reflects that the correlation among all the indicator variables is significant in forming the latent variables.Based on the data analysis results, when viewed from the loading estimate value obtained by each indicator, the non-financial performance indicator with the statement item "market increase" most dominantly reflects the Company's Performance variables.

The AVE value of 0.2382 . When compared with the square root of the AVE value of the Financial Decision variable with the correlation value between other latent variables in the model, it can be said that this variable has good discriminant validity because the square root of the AVE value is greater than the correlation value of all other latent variables. Thus, the research instrument used to measure the Financial Decision variable meets the criteria for discriminant validity. Data analysis results using the GSCA method show that the alpha value obtained is 0.7257 , which means that this variable has the right internal reliability consistency because it is more significant than 0.6.

The test results show that the Financial Decisions of managers and owners of SMEs are most reflected by the non-financial performance indicators with the statement "market increase" with a mean value of 3.09. This valuemeans not all managers and owners of SMEs have experienced an increase in their business market.

\subsubsection{Structural Model}

In this structural model, 5 (five) hypotheses were tested. There are 3 (three) assumptions accepted and shown in Figure 4.1.

Figure 4.1.

\section{ResearchStructural Model}

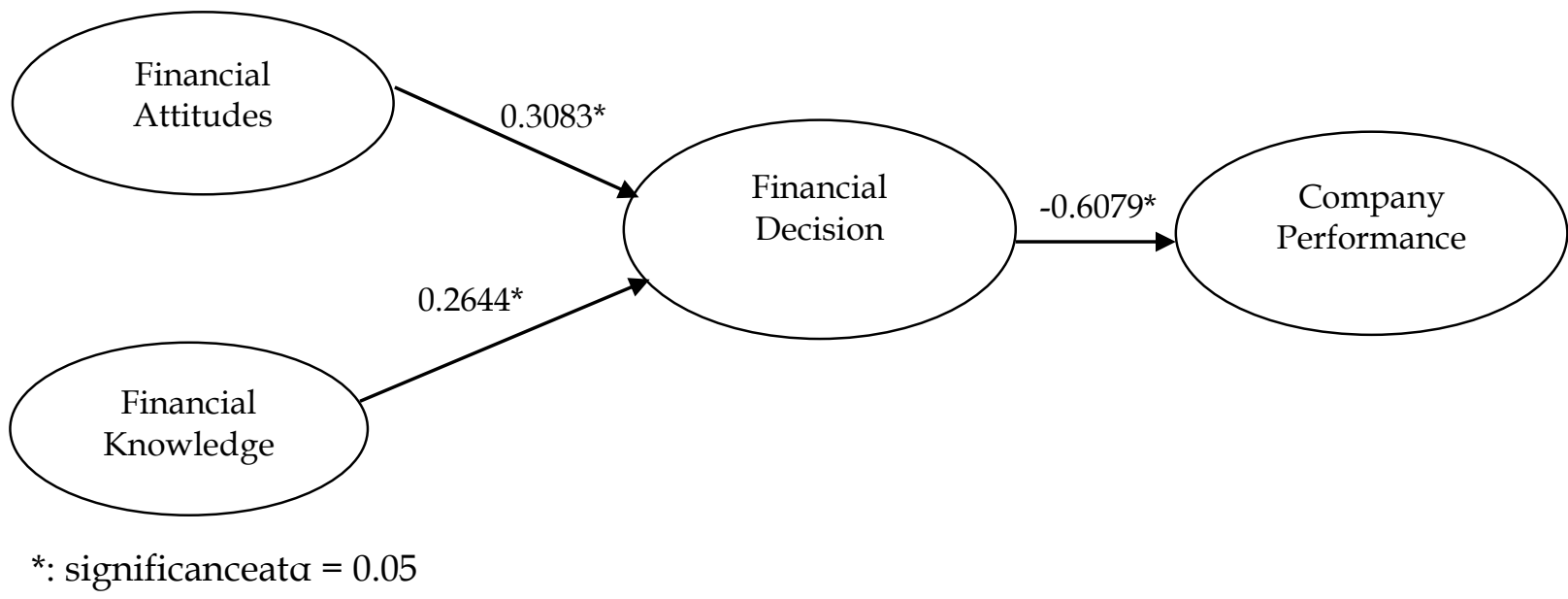


Hypothesis testing is as follows:

a. The coefficient value of the influence of Financial Attitudes on Financial Decisions is 0.3083. It is significant, meaning that the better the Financial Attitudes of SMEs and SMEs owners, the better in making Financial Decisions.

b. The coefficient value of the influence of Financial Knowledge on Financial Decisions is 0.2644. It is significant, meaning that the better the Financial Knowledge managers and SMEs owners, the better in making Financial Decisions.

c. The coefficient value of the influence of Financial Decisions on Company Performance is -0.6079. It is significant, meaning that the better the manager and owner of SMEs in making Financial Decisions, the lower the Company's performance.

The calculation of the coefficient of the indirect effect is obtained from the multiplication of 2 (two) values of the direct effect coefficient. The indirect impact is declared significant if the Sobel test has been carried out, z_value, calculated by dividing the standard error's direct effect coefficient. The results of the indirect effect test are presented in Table 4.6.

Table 4.6.

Indirect Effect Testing Results

\begin{tabular}{|c|c|c|c|c|c|c|c|}
\hline \multirow{2}{*}{$\begin{array}{l}\text { IndirectEffect } \\
\text { Financial } \\
\text { Attitude>Fina } \\
\text { ncial } \\
\text { Decision>Com } \\
\text { pany } \\
\text { Performance }\end{array}$} & \multicolumn{4}{|c|}{ Direct Effect Coefficient Value } & \multirow{2}{*}{$\begin{array}{c}\begin{array}{c}\text { Indirect } \\
\text { Effect } \\
\text { Coefficient } \\
\text { Value }\end{array} \\
-0,1874\end{array}$} & \multirow{2}{*}{$\begin{array}{l}\text { P-Value } \\
\\
0,5\end{array}$} & \multirow{2}{*}{$\begin{array}{l}\text { Description } \\
\begin{array}{l}\text { Mediation is } \\
\text { insignificant }\end{array}\end{array}$} \\
\hline & $\begin{array}{l}\text { Financial } \\
\text { Attitude>Fina } \\
\text { ncial Decision }\end{array}$ & 0,3083 & $\begin{array}{l}\text { Financial } \\
\text { Decision> } \\
\text { Company } \\
\text { Performa } \\
\text { nce }\end{array}$ & $-0,6079$ & & & \\
\hline $\begin{array}{l}\text { Financial } \\
\text { Knowledge }>\mathrm{Fi} \\
\text { nancial } \\
\text { Decision>Com } \\
\text { pany } \\
\text { Performance }\end{array}$ & $\begin{array}{l}\text { Financial } \\
\text { Knowledge }>\text { Fi } \\
\text { nancial } \\
\text { Decision }\end{array}$ & 0,2644 & $\begin{array}{l}\text { Financial } \\
\text { Decision> } \\
\text { Company } \\
\text { Performa } \\
\text { nce }\end{array}$ & $-0,6079$ & $-0,1607$ & 0,5 & $\begin{array}{l}\text { Mediation is } \\
\text { insignificant }\end{array}$ \\
\hline
\end{tabular}

Description: $>=$ to

\subsection{Discussion of Research Results}

\subsubsection{The Effect of Financial Attitudes on Financial Decisions}

Financial Attitudes have a positive and significant effect on Financial Decision making by the manager and owner of SMEs. This means that the better the Financial Attitudes owned by the SMEs owner, the better it is in making Financial Decisions. Calculations support this todeterminecompany operations expenditures, especially in judgments on placing funds for working capital. This is motivated by the age of most of the respondents of productive age, mostly male, most of the education level is high school, and the length of business is more than 10 (ten) years.

These findings broaden the study of behavioral finance. More specifically, this research results in the discovery that SMEs managers' Financial Attitudes as reflected by the retention indicator have a positive and significant effect on Financial Decision-making as reflected by investment decisions, namely the placement of funds for working capital. The results of this study are consistent with research conducted by Mien and Thao (2015), Amanah et al. (2016), Wiharno (2018), and Humairo (2018). 


\subsubsection{The Influence of Financial Knowledge on Financial Decisions in SMEs}

Financial Knowledge has a positive and significant effect on Financial Decision making by the owner and owner of SMEs. This means that the better the Financial Knowledge possessed by SMEs owners, the better it is in making Financial Decisions. This is reflected in SMEs owners' risk management in making Financial Decisions: a) Identifying exposures to the risks faced; b) Identifying the financial impact of the risks faced; c) Choose the most appropriate way to deal with these risks. This is also motivated by the age of most of the respondents of productive age, mostly men, the education level of most of them isthehigh school, and the length of business is more than 10 (ten) years.

These findings broaden the study of behavioral finance. More specifically, this research results in findings that the Financial Knowledge possessed by SMEs managers as reflected by the risk management indicator has a positive and significant effect on Financial Decision making as reflected by investment decisions, namely the placement of funds for working capital. The results of this study are also from research conducted by Mien and Thao (2015), Amanah et al. (2016), Wiharno (2018), and Humairo (2018).

\subsubsection{The Influence of Financial Attitude Affects Company Performance with Financial Decisions as an Intervening Variable}

Financial Decisions do not mediate the effect of Financial Attitude on Company Performance. Financial Attitude, which is reflected by retention, spending money with a reasonable calculation (economic) can produce the right Financial Decisions. On the other hand, the Financial Decisions taken have a significant adverse effect on Company Performance. SMEs managers feel that the rightFinancial Decisions that have been taken cannot improve Company Performance. This is because decision-making is carried out individually and often based on intuition so that the decisions taken cannot improve SMEs performance. Financial choices reflected in the indicator of investment decisions by placing funds for working capital with the statement item "checking the level of bad credit" reflect the variable Financial Decisions. Based on the respondents' average score, not all SMEs owners carry out unpaid accounts receivable checks to check on lousy credit levels is ineffective. As a result, there is a tendency to decline in the SMEs market share. This is indicated by the mean score of respondents' answers below 4 (four) for market improvement.

This study's results state that Financial Decisions cannot mediate Financial Attitude on Company Performance. This indicates that Financial Attitude has a direct effect on Company Performance, such as the results of research conducted by Tuffour et al. (2020) stated that the financial literacy (awareness, attitude, and knowledge) of SMEs managers has a positive and significant effect on the performance (financial and non-financial) of SMEs in Ghana.

\subsubsection{The Influence of Financial Knowledge Influences on Company Performance with Financial Decisions as an Intervening Variable}

Financial Decisions do not mediate the effect of Financial Knowledge on Company Performance. Financial Knowledgeis reflected by risk management with the statement, "I apply risk management in makingFinancial Decisions: a) Identifying exposures to the risks faced; b) Identifying the financial impact of the risks faced; c) Choose the most appropriate way to deal with these risks. ". On the other hand, the Financial Decisions taken have a negative and significant effect on Company Performance. SMEs managers feel that the Financial Decisions that have been taken are not able to improve Company Performance. Financial Decisions are reflected in the investment decision indicator by placing funds for 
working capital with the statement item "checking the level of bad debts" most dominantly reflect the variable Financial Decisions. Financial Decisions taken have a significant adverse effect on Company Performance. This illustrates the weak ability in decision-making in SMEs (Idrus, 1999: 18); SMEs managers feel that the Financial Decisions taken are fixed; in fact, they cannot improve Company Performance. Financial Decisions are reflected in the investment decision indicator by placing funds for working capital with the statement item "checking the level of bad debts" most dominantly reflect the variable Financial Decisions. Based on the respondents' average score, not all SMEs owners check for unpaid accounts, so that the check for harmful credit levels is ineffective, resulting in a tendency to decline in the SME market share. This is indicated by the mean score of respondents' answers below 4 (four) for market improvement.

This study's results state that Financial Decisions cannot mediate the effect of Financial Knowledge on Company Performance. This indicates that Financial Knowledge has a direct effect on Company Performance, such as the results of research conducted by Tuffour et al. (2020) stated that the financial literacy (awareness, attitude, and knowledge) of SMEs managers has a positive and significant effect on the performance (financial and nonfinancial) of SMEs in Ghana.

\subsubsection{The Effect of Financial Decisions on Company Performance}

Financial Decisions taken have a negative and significant effect on Company Performance. SMEs managers feel that the Financial Decisions that have been taken are correct; in fact, they cannot improve Company Performance, or in other words, there is a tendency to decline in market share. This is due to the weak ability in decision making in SMEs. Decision-making is done individually and often intuitively. Financial Decisions reflected in the indicator of investment decisions by placing funds for working capital with the statement item "checking the level of bad credit" reflect the variable Financial Decisions. The Company's Performance is reflected by the non-financial performance indicators with the statement item "market increase" reflecting the Company's Performance variable. Empirical data in the form of the mean score results (below 4) of the two variables, namely Financial Decisions and Company Performance, show that SMEs owners are still weak in making decisions so that the Company'sperformance is not optimal.

This study's results state that the results of Financial Decisions that are felt by managers are appropriate; in fact, it results in a decline in Company Performance as reflected by the SMEs market share. This finding is supported by Syahrir et al. (2019), which states that Financial Decisions have a negative and significant effect on Company Performance.

\section{CONCLUSIONS AND SUGGESTIONS}

\subsection{Conclusions}

Based on hypothesis testing, discussion results, and research findings, several conclusions can be made as follows:

1. Financial Attitude has a positive and significant effect on Financial Decision making by the manager and owner of SMEs. This means that the better the Financial Attitudes owned by the SMEs owner, the better it is in making Financial Decisions.

2. Financial Knowledge has a positive and significant effect on Financial Decision making by the manager and owner of SMEs. This means that the better the Financial Knowledge possessed by SMEs owners, the better it is in making Financial Decisions.

3. Financial Decisions cannot mediate the effect of Financial Attitude on Company Performance. 
4. Financial Decisions cannot mediate the influence of Financial Knowledge on Company Performance.

5. Financial Decisions have a negative and significant effect on Company Performance. SME managers feel that the Financial Decisions taken are correct. In fact, they cannot improve Company Performance or, in other words, a tendency to decline in market share. This is due to the weak ability in decision making in SMEs. Decision-making is done individually and often intuitively.

\subsection{Suggestions}

Based on this study's results and conclusions, it can be suggested that it becomes a recommendation for future research.

1. In future research, it is hoped that the research sample will be limited to pottery SMEs that are exported only because there are still many export SMEs that are developing in the community, such as bamboo and wood handicraft SMEs.

2. Future research is expected not only on profit organizations but also on non-profit organizations, government officials, and households so that financial behavior can be found in other research objects.

\section{REFERENCES}

Akhtar, Sharmin and Liu, Yanping. 2018. SME Managers and Financial Literacy; Does Financial Literacy Really Matter?.Journal of Public Administration and Governance, Vol 8, No. 3, pp. 353-373.

Amanah, RahadiandanIradianty, 2016, PengaruhFinancial Knowledge, Financial AttitudesdanExternal Locus of ControlterhadapPersonal Financial ManagementBehaviorpadaMahasiswa S1 Universitas Telkom, e-Proceeding of Management, Vol-3, No. 12. Agustus 2016, Page 1228.

De Bondt, W. et al. 2008. Behavioral Finance: Quo Vadis?.Journal of Applied Finance; Fall2008; 18, 2; ABI/INFORM Research.

Eagly and Chaiken. 1993. The Psychology of Attitudes. Fort Worth, TX: Harcourt, Brace, \&Janovich, $794 \mathrm{pp}$.

Forbes, William.2009. Behavioural Finance. First Edition. John Wiley \& Sons Ltd.

Gumanti, AryTatang. 2009, Behavior Finance: SuatuTelaah. Usahawan No. 1/Th, XXXVIII

HerdjionodanDamanik. 2016. PengaruhFinancialAtitude, Financial Knowledge, Parental IncometerhadapFinancial Management Behavior. JurnalManajemenTeoridanTerapan.Tahun 9. No. 3, Desember 2016

Idrus, M. Syafiie. 1999. StrategiPengembanganKewirausahaan (Entreprenuership) danPerananPerguruanTinggidalamRangkaMembangunKeunggulanBersaing (Competitive Advantage) Bangsa Indonesia padaMilleniumKetiga, Makalahtidakdipubilkasikan, UniversitasBrawijaya Malang.

Jermias, Johnny and Gani, Lindawati. 2005. Ownership Structure, Contingent-fit, and Business-unit Performance: A Research Model and Empirical Evidence. The InternationalJournal of Accounting, vol. 40, pp. 65-85

Klontz, Britt, Mentzer and Klontz. 2011. Money Beliefs and Financial Behaviors: Development of the Klontz Money Script Inventory, The Journal of Financial Therapy. Volume 2, Issue 1.

Liantodan Elizabeth. 2017. AnalisisPengaruhFinancial Attitude, Financial Knowledge, Income terhadap Financial Behavior di KalanganIbuRumahTangga Palembang 
(StudiKasusKecamatanIlirTimur I). http://eprints.mdp.ac.id/2365/. Diakses 22 November 2019.

Mien, Nguyen Thi Ngoc and Thao, ThranPuong. 2015. Factors Affecting Personal Financial Management Behaviors: Evidence from Vietnam.Proceedings of the Second AsiaPacific Conference on Global Business, Economics, Finance and Social Sciences (AP15Vietnam Conference).

NababandanSadalia (2012), Analisis Personal Financial Literacy dan Financial Behavior Mahasiswa Strata I FakultasEkonomiUniversitas Sumatera Utara, Jurnal Online, http://jurnal.usu.ac.id/index.php/jmim/article/view/651.

Nyamao, Patrick, Martin, Odondo and Simeyo. 2012. Effect of working capital management practices on financial performance: A study of small scale enterprises in Kisii South District, Kenya. African Journal of BusinessManagement, Vol. 6, pp. 5807-5817.

Ricciardi V. and Simon, H, K. 2000. What is Behaviour in Finance. Business, Education, and Technology Journal, Vol. 2, No. 2, pp. 1-9.

Sherin. 2007. Beyond Greed and Fear: Understanding BehaviourFinance and Psychology of Investing, Harvard Business School Press, Boston, USA.

Solimun. 2012. PemodelanPersamaanStruktural: GeneralizedStructured Component Analysis GSCA. MateriPelatihanStatistikaMultivariat. Fakultas MIPA. UniversitasBrawijaya.

Sugiyono. 2008. MetodePenelitianBisnis (PendekatanKuantitatif,Kualitatifdan $R \quad \mathcal{E} \quad D$ ). CV. Alfabeta. Bandung.

SupramonodanPutlia, Nancy. 2010.PersepsidanFaktorPsikologisdalamPengambilanKeputusanHutang. JurnalKeuangandanPerbankan, Vol. 14, No. 1 Januari 2010, hal. 24-35.

Syahrir, Alam Dan Sanusi. 2019. KeputusanKeuangan, EfisiensiOperasional, Dan InovasiTerhadapPeningkatanKinerjaKeuangan Dan Nilai Perusahaan Pada Perusahaan Farmasi Di Bursa Efek Indonesia. JBMI Vol. 6, No.1.

Tuffour, Amoaka and Amartey. 2020. AssessingtheEffectofFinancialLiteracy AmongManagersonthePerfor manceofSmall-ScaleEnterprises. Global Bussines Review, pp. 1-18.

Pompian, Michael M.2006. Behavioral Finance and Wealth Management. John Wiley \& Sons, Inc. New Jersey.

Van Horne, James C. 2002. Financial Management and Policy. Twelfth Edition. Prentice Hall Upper Saddle River. New Jersey.

Wiharno, Herma. 2018. PengaruhFinancial Knowledge, Financial Behavior danFinancialAttitudeterhadapPersonal Financial Management.JRKA Volume 4 Isue 1, Februari 2018: 64-76.

http://diskop.ntbprov.go.id/data/2019/05/DATA-UMKM-2018-1.jpg. $\quad$ Diakses 22 November 2019. 